\title{
Ten reasons why we should not abandon a detailed first trimester anomaly scan
}

\author{
Zehn Gründe, warum wir eine detaillierte Ersttrimester-Fehlbildungsdiagnostik \\ nicht aufgeben sollten
}

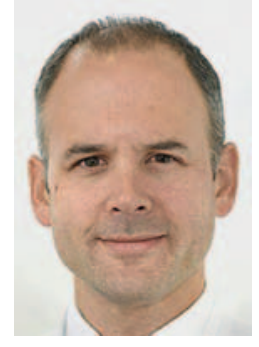

Karl Oliver Kagan

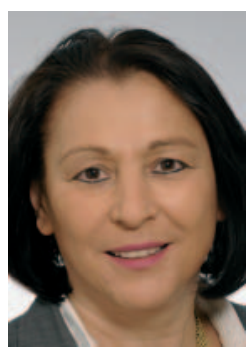

Sevgi Tercanli

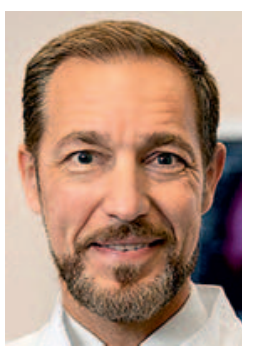

Markus Hoopmann
Correspondence

Prof. Dr. Karl Oliver Kagan

University Hospital of Tuebingen

Department of obstetrics and gyaecology, Calwerstraße 7,

72076 Tübingen, Deutschland

Tel.: +49/70 71/2984807

KOKagan@gmx.de
Bibliography

Ultraschall in Med 2021; 42: 451-459

DOI 10.1055/a-1528-1118

ISSN $0172-4614$

(c) 2021. Thieme. All rights reserved.

Georg Thieme Verlag KG, Rüdigerstraße 14,

70469 Stuttgart, Germany

\section{Introduction}

Within the last two decades, the first trimester screening at 1113 weeks' gestation has evolved from a simple measurement of the nuchal translucency (NT) thickness and the crown-rump length (CRL) towards a detailed risk stratification for several complications that may happen within the course of the pregnancy $[1,2]$. As a consequence, first trimester screening is now considered crucial for the management of each pregnancy. It involves a detailed risk assessment for chromosomal abnormalities, especially for trisomy 21 , for preeclampsia and fetal growth restriction as well as a detailed anomaly scan [3-9]. In a meta-analysis from Karim et al., the detection rate for fetal defects in a high risk population exceeded $60 \%$ [5]. These positive aspects have resulted in the concept of "turning the pyramid of pregnancy care". In short, this model relies on a detailed first trimester risk assessment and stratifies the further management of the pregnancy according to the respective risk profile [10].

The increasing availability of the cell free DNA analysis (cfDNA) in screening for trisomy 21 has introduced alternative pregnancy care models that may challenge the concept of an extended first trimester screening program [11, 12]. The most commonly discussed alternative concept consists in a cfDNA analysis at or even before 10 weeks combined with a basic ultrasound examination [13]. The purpose of the latter would be to examine if the embryo is alive, measure the CRL for dating and determine the chorionicity in case of a multiple pregnancy. All other first trimester screening options would be ignored and the early anatomical assessment would be abandoned in favor of a detailed second trimester anomaly scan.

Although most fetal medicine experts would intuitively question such an approach, there are some arguments in favor of such a policy.

Three of them are highlighted here:

First, many health authorities consider screening for trisomy 21 still as the main aim of the combined first trimester screening test. The detection and false positive rate is about $95 \%$ and $2.5-5 \%$, respectively [4]. In contrast, screening by cfDNA provides rates of $99 \%$ and $0.1 \%$ [14]. So why should a screening test that is worse be kept in place instead of using a better test?

Second, in most countries, one anomaly scan per pregnancy is implemented, that is carried out in the second trimester. Pregnant women are aware of this midtrimester anomaly scan and obstetricians are trained to identify anomalies at this gestational age. The first trimester anomaly scan is carried out in addition to the second trimester ultrasound examination without replacing the latter. From a health economic point of view, one could question the need of an additional anomaly scan in the first trimester: the resources for two detailed ultrasound examinations during the course of the pregnancy are not available, most obstetricians are trained to perform the detailed ultrasound in the second trimester, it is generally easier to detect anomalies in the second 
trimester due to the size of the fetus and lastly, there are fewer unclear findings in the second trimester that require additional follow-up examinations than in the first trimester.

Third, there is no doubt that some anomalies such anencephaly can be detected in the first trimester with a high level of certainty [11]. A single anomaly scan at about 20 weeks would mean that the detection of these kind of fetal defects would be postponed although they could have been detected two months earlier. However, most of these severe anomalies result in a termination of pregnancy or in a postnatal palliative care- irrespective of the gestational age at the time of diagnosis. Thus, the level of maternal stress level might be increased if the diagnosis is postponed in the second trimester but the overall outcome remains unchanged.

However, a model that is based on a cfDNA test at about 10 weeks and one single detailed ultrasound examination in the second trimester carries substantial disadvantages.

\section{Ten good reasons for an early anomaly scan}

In the following part of our review we discuss 10 reasons that highlight the importance of an early anomaly scan at 11-13 weeks of gestation. These arguments emphasize the benefits of a detailed first trimester ultrasound examination as a "planning and management" scan that should not be abandoned in favor of a test which only performs better for trisomy 21 alone.

\section{Frequency of fetal defects and chromosomal abnormalities}

Pregnancy care should be guided by the incidence of complications in pregnancy and not by the performance of available screening tests. Due to the excellent detection and false positive rate of cfDNA screening for trisomy 21 , one is tempted to focus primarily on trisomy 21 although other pregnancy complications are much more common [15]. In short, the risk for trisomy 21 raises from about 1:1.250 in a 20 year old women to about 1:90 in a 40 year old women. In contrast, the risk for rare chromosomal defects is 1:270 and for major defects, preeclampsia, intrauterine growth restriction and preterm delivery, it is about 2\%, $2 \%, 5 \%$ and $10 \%$, respectively [15-17]. Some of these complications can be addressed by first trimester screening. Regarding preeclampsia, it was shown that combined screening for early preeclampsia at 11-13 weeks can detect about three quarters of the affected pregnancies for a false positive rate of $10 \%$ [6]. More importantly, Rolnik et al. showed that in the high risk population, defined by first trimester screening, it was possible to reduce the risk for early preeclampsia by up to $80 \%$ with the use of Aspirin [7]. The fact, that major defects and preeclampsia are more common than trisomy 21 and that there is a prophylaxis against preeclampsia for high risk patients identified at 11-13 weeks underlines the importance of a detailed first trimester risk assessment.

\section{Detection rate of fetal defects in pregnancy}

Most antenatal care programs focus on the second trimester ultrasound examination as the most relevant scan for the detection of fetal defects. This approach implies that the detection rate of fetal defects at this gestation is reasonably high. However, in the Eurocat registry, the detection rate for fetal defects during the whole course of the pregnancy is only about $40 \%$ [18]. Similarly, in a meta-analysis from the German Institute for Quality and Efficiency in Health Care, the detection rate for fetal defects was $44,5 \%$ for a false positive rate of $0,1 \%$ [19]. Rydberg and Tunon observed the similar detection and false positive rates [20]. Their study was based on more than 10.000 pregnancies and 243 fetuses with major defects.

These rates are disappointing, especially in direct comparison with the test performance of the available screening tests for common trisomies [21].

There are essentially two different approaches to increase the detection rate of major defects: a better training program for the medical professionals and/or an extension of the time interval where the fetus is examined.

The second approach seems more promising. In a meta-analysis from Karim et al., the detection rate for major fetal defects at $11-13$ weeks was $46 \%$ and in a high risk population, it was even $61 \%$, respectively [5]. Liao et al. reviewed the outcome of more than 50.000 first trimester anomaly scans and reported on a detection rate of $43 \%$ [22].

Thus, the detection rate for fetal defects of the first trimester scan is similar to the overall detection rate in pregnancy and in a high risk population, it is even higher. We acknowledge that we compare data from first trimester studies with clinical data from the second trimester but there are no recent studies that examine the detection rate of fetal defects in the second trimester in a study setup.

The high risk population could be defined with the use of surrogate markers such as the nuchal translucency thickness, the ductus venosus flow or fossa posterior markers [23-29]. These markers are well known first trimester markers showing a strong association with major structural defects.

In summary, the second trimester ultrasound examination fails to detect a reasonable proportion of fetal defects. The first trimester scan provides at least similar detection rates. Even if the second trimester anomaly scan would be replaced by the first trimester anomaly scan with the use of first trimester surrogate markers, one can speculate that the detection rate would be similar or even increased. The most powerful approach, however, is a combined use of both, the first and second trimester scan with detection rates of more than $80 \%$ [30].

\section{Obesity}

Obesity is one of the major burdens in medicine with increasing impact on obstetrics and on prenatal medicine [31, 32]. Estwood et al. demonstrated that image quality deteriorated as BMI increases. In their study, in the group of women with a BMI of $40 \mathrm{~kg} / \mathrm{m} 2$ or more, almost a quarter of the second trimester ultrasound examinations were incomplete [33]. Others have shown similar results and highlighted the need of an additional ultrasound examination later on to complete the anatomical evaluation [34].

An early anatomical assessment at 11-13 weeks' gestation could be an beneficial alternative. In contrast to the second tri- 
mester evaluation, the first trimester scan can be done with the use of the transvaginal probe and gentle pressure on the maternal abdomen. In most cases, the anatomical assessment in obese women can be done with more success at this early gestation than at 20 weeks. This was also shown by Toscano at al. who compared the effectiveness of the first and second trimester anatomical assessment in women with a BMI $>35 \mathrm{~kg} / \mathrm{m} 2$ [35]. Fetal anatomic survey was completed in $62 \%$ using the second trimester assessment versus $78 \%$ with the addition of early transvaginal assessment. The authors concluded, that incorporation of an early transvaginal assessment of anatomy in obese women improves the rate of completion and leads to earlier gestational age at completion of the fetal anatomic survey.

\section{Visualization of fetal structures}

Numerous studies have shown that at 11-13 weeks' gestation, some specific anomalies can be diagnosed in almost all cases. This group consists of anencephaly, holoprosencephaly, abdominal wall defects, body stalk anomaly and megacystis [11].

Some anomalies can be seen even better in the first than in the second trimester. These are gastroschisis and small omphaloceles containing bowel only, retrognathia as well as hand and finger defects. We acknowledge that this is our personal experience and there are no studies to support this observation. However, in terms of abdominal wall defects and hand defects, diagnosis can be challenging in cases with reduced amniotic fluid at later gestation. Additionally, retrognathia is generally most pronounced in the first trimester [36].

\section{Inconclusive and insufficient cell free DNA tests}

Although cfDNA screening provides a high test performance in screening for common trisomies, there are two weaknesses that need to be taken into account.

First, about $2-5 \%$ of the cfDNA tests remain uninformative, mainly due to low fetal fraction below the threshold of $4 \%$ [37-39]. The cfDNA test can be repeated some weeks later as the average fetal fraction increases by $0,1 \%$ per gestational week. About two thirds of these tests are successful after the second analysis [38]. However, if the cfDNA test remains uninformative, the women will not benefit from an early risk assessment for trisomy 21 anymore. Another repeat analysis will not increase the success rate any further and the first trimester combined test will not be possible any more due to the increased gestational age. Given the fact that the second trimester anomaly scan has a lower detection rate in screening for trisomy 21 , diagnostic testing is the only alternative to assess the aneuploidy risk [40]. If all women with an inconclusive cfDNA test opt for invasive testing, the most relevant beneficial effect of cfDNA screening - low invasive testing rate - will be diluted [41].

If cfDNA testing is done at 11-13 weeks, the nuchal translucency thickness can be measured at the same time when blood is taken for cfDNA screening and another blood sample can be drawn and stored. If cfDNA testing is inconclusive, PAPP-A and free beta-hCG can be measured in the stored sample and the first trimester combined risk can be used for the risk assessment [26].
Second, as shown in our first argument, there are many more chromosomal abnormalities than just those ones that can be detected by cfDNA testing. A large proportion of these cases have an increased nuchal translucency thickness, severely abnormal serum markers or major fetal defects [26, 42-46]. These findings should trigger diagnostic testing instead of a cfDNA test. Of course, major anomalies can be seen in the second trimester, too, but the other hints towards a rare chromosomal defect are not available anymore at 20 weeks' gestation.

\section{Timing}

Contemporary genetic analysis involves cytogenetic and microarray analysis as well as next generation sequencing (NGS) $[47,48]$. In general, the indication for the diagnostic test determines the genetic analysis. If there is a suspected trisomy, cytogenetic analysis is still the method of choice expanded by a microarray if required. However, in case of multiple anomalies without cytogenetic or microarray pathology, NGS methods are indicated. The most relevant disadvantage of the latter is, that it is currently not carried out as first line analysis but as a secondary test and that it still takes 2-4 weeks until a result is available. The explanation for such an approach goes beyond the scope of this paper.

If the diagnosis of a fetal defects is postponed until 20 weeks, the time interval between counseling, decision making in view of the diagnostic testing and the final result of the genetic test may involve several weeks. As a consequence, if the couple opts for termination of pregnancy, it would need to be carried out in the third trimester. In several countries, there are legal restrictions that do not allow such a late termination.

In contrast, if the fetal defect is already identified at 11-13 weeks, there is enough time to finalize the whole diagnostic process until 20 weeks.

\section{Women's choice}

To the best of our knowledge, there are no studies that examined if women prefer a first or a second trimester ultrasound examination for the detection of fetal defects. However, there are older studies showing that if women could choose, they would opt for first trimester screening for trisomy 21 rather than second trimester screening [49]. A large proportion of the pregnant women have limited knowledge about Down syndrome. For them, trisomy 21 is a substitute for an array of disabilities in the fetuses and newborns. Consequently the screening for trisomy 21 has for them a much larger scope than just trisomy 21 .

One can assume that if screening in the first trimester is the preferred choice and if trisomy 21 is just a surrogate for a child with disabilities, the preferred time for the assessment of the fetal anatomy would at 11-13 weeks' gestation.

The next three arguments focus on termination of pregnancy and its complications. They underline that termination of pregnancy is safer with less long term complications if it is done in the first compared to the second trimester. Thus, screening for aneuploidy as well as major defects should be done as early as possible to prevent late terminations. 


\section{Risks of termination of pregnancy}

With increasing gestational age, the maternal risk of a termination of pregnancy increases. Bartlett et al. examined the maternal mortality rate after termination of pregnancy and observed an increase of $38 \%$ per each week [50]. Mark et al. focused on the morbidity in cases with surgical termination [51]. The overall complication rate was $2,2 \%$. In the second trimester the complication rate was double compared to the first trimester group. This was particularly true for obese women. For instance, in women with a BMI of $40 \mathrm{~kg} / \mathrm{m} 2$ and more, the complication rate in the first trimester was $1,1 \%$ and in the second trimester $8,7 \%$.

\section{Psychological consequences of termination of pregnancy}

Termination of pregnancy can result in long-lasting mental health problems for both partners. Korenromp et al. observed posttraumatic stress and symptoms of depression in $44 \%$ and $28 \%$ of the women after termination of pregnancy, respectively. The partners were affected in $22 \%$ and $16 \%$ of the cases [52]. The authors searched for predictors for an adverse psychological outcome and found that advanced gestational age was significantly associated with psychological complications. Similarly, Davies et al. found an increased post-traumatic stress 6 weeks after second trimester termination compared to first trimester termination of pregnancy [53].

\section{Dichorionic twin pregnancy with major defects}

Decision making in cases with dichorionic diamniotic twin pregnancies with major defects in one fetus is particularly difficult. The wish to protect the healthy co-twin stands against the potential aim to terminate the pregnancy with fetal anomalies. The method of choice is a selective termination which consists of a fetocide of the affected fetus and continuation of pregnancy. However, timing is of critical importance for this approach.

Zemet al. examined the outcome of selective terminations in dichorionic twin pregnancies between 15 and 23 weeks. $28 \%$ of the healthy co-twins were born preterm and $12.0 \%$ before 34 weeks, respectively [54] In contrast, selective terminations carried out between 11 and 14 weeks resulted in a preterm delivery rate of $14 \%$ and only $1,8 \%$ of the co-twins were born before 34 weeks' gestation.

In conclusion to the arguments listed above, we have shown that the increasing number and variety of prenatal diagnostic tools must not lead to abandon the proven benefits of a detailed first-trimester anomaly scan, but rather places increased and more complex demands on it. The qualified ultrasound in the first trimester must retain its crucial planning and triage function in order to ensure optimal pregnancy care.

\section{Einleitung}

In den letzten 2 Jahrzehnten hat sich das Ersttrimester-Screening zwischen 11-14 Schwangerschaftswochen (SSW) von einer einfachen Bestimmung der Nackentransparenz (NT) und der ScheitelSteiß-Länge (SSL) zu einer detaillierten Risikostratifizierung für verschiedene Komplikationen weiterentwickelt, die im Schwangerschaftsverlauf auftreten können [1, 2]. Infolgedessen wird das Ersttrimester-Screening heute als entscheidend für das Management jeder Schwangerschaft angesehen. Es umfasst eine detaillierte Risikobewertung für Chromosomenanomalien, insbesondere für die Trisomie 21, Präeklampsie und auch für die fetale Wachstumsrestriktion sowie für eine detaillierte Fehlbildungsdiagnostik [3-9]. In einer Metaanalyse von Karim et al. lag die Detektionsrate für fetale Fehlbildungen in einer Hochrisikopopulation bei über $60 \%$ [5]. Diese positiven Aspekte haben zu dem Konzept der „Umgedrehten Pyramide der Schwangerenbetreuung " geführt. Zusammengefasst bedeutet dies, dass dieses Modell auf einer detaillierten Risikobewertung im ersten Trimester basiert und das weitere Management einer Schwangerschaft nach ihrem individuellen Risikoprofil stratifiziert [10].

Der rasante zunehmende Einsatz der zellfreier DNA (cfDNA) für das Screening auf Trisomie 21 impliziert nun alternative Schwangerschaftsvorsorgemodelle, die das Konzept des erweiterten Ersttrimester-Screenings infrage stellen könnten [11, 12]. Das am häufigsten diskutierte alternative Konzept besteht in der Durchführung des Nicht-Invasiven Pränataltests (NIPT) bereits mit 10 SSW oder früher in Kombination mit einer Basis-Ultraschalluntersuchung [13]. Die Zielsetzung hierbei wäre, die Vitalität des Embryos zu überprüfen, die Scheitelsteisslänge zur Bestimmung des Gestationsalters zu messen und die Chorionizität bei Mehrlingsschwangerschaften zu diagnostizieren. Alle übrigen diagnostischen Möglichkeiten des Ersttrimester-Screening würden unbeachtet bleiben. Damit würde die frühzeitige Beurteilung der fetalen Anatomie zugunsten einer detaillierten ZweittrimesterFehlbildungsdiagnostik aufgegeben werden.

Obwohl die meisten Pränatalmediziner einen derartigen Ansatz intuitiv hinterfragen würden, gibt es einige Argumente, die für diese Strategie sprechen.

Drei davon sollen an dieser Stelle diskutiert werden:

Erstens gilt für viele Gesundheitsbehörden das Screening auf Trisomie 21 immer noch als das Hauptziel eines kombinierten Ersttrimester-Screenings. Die Detektionsrate beträgt etwa $95 \%$ und die Falsch-Positiv-Rate 2,5-5\% [4]. Im Gegensatz dazu liegt beim cfDNA-Screening die Detektionsrate bei $99 \%$ und die Falsch-Positiv-Rate bei $0,1 \%$ [14]. Warum also sollte ein schlechterer Screeningtest beibehalten werden, wenn man einen besseren Test einsetzen kann?

Zweitens wird in den meisten Ländern ein Fehlbildungsultraschall pro Schwangerschaft im zweiten Trimester durchgeführt. Die Schwangeren kennen diese Untersuchung, und die Frauenärzte sind darin geschult, Fehlbildungen in diesem Gestationsalter zu erkennen. Die Ersttrimester-Fehlbildungsdiagnostik würde zusätzlich zur Ultraschalluntersuchung im zweiten Trimester durchgeführt, ohne diese zu ersetzen. Aus gesundheitsökonomischer Sicht könnte man den Nutzen einer zusätzlichen Ersttrimester-Fehlbildungsdiagnostik infrage stellen: Die Mittel für zwei detaillierte Ultraschalluntersuchungen im Verlauf der Schwangerschaft sind begrenzt; die meisten Frauenärzte sind für die detaillierte Zweittrimester-Ultraschalluntersuchung ausgebildet; es ist allgemein einfacher, aufgrund der Größe des Feten Anomalien im zweiten Trimester zu erkennen; und nicht zuletzt gibt es im 
zweiten Trimester weniger unklare Befunde, die zusätzliche Nachuntersuchungen erfordern als im ersten Trimester.

Drittens gibt es keinen Zweifel daran, dass man einige Fehlbildungen wie die Anenzephalie mit hoher Sicherheit im ersten Trimester erkennen kann [11]. Eine einzige Fehlbildungsdiagnostik mit 20 Schwangerschaftswochen würde bedeuten, dass die Entdeckung dieser Fehlbildungen verzögert wird, obwohl sie bereits 2 Monate früher hätte erkannt werden können. Allerdings führen die meisten dieser schweren Anomalien zum Schwangerschaftsabbruch oder zur postnatalen Palliativversorgung - unabhängig davon, wann die Diagnose gestellt wird. Dadurch könnte die Belastung für die Schwangere größer sein, wenn die Diagnose einer Anomalie in das zweite Trimester verlegt wird, auch wenn das Outcome grundsätzlich unverändert bleibt.

Allerdings birgt ein Modell mit 10 SSW basierend auf einem Screeningtest für eine Trisomie 21 und einer einzigen detaillierten Ultraschalluntersuchung im zweiten Trimester erhebliche Nachteile.

\section{Zehn gute Gründe für eine frühzeitige Fehlbildungsdiagnostik}

Im nun folgenden Teil unserer Übersicht diskutieren werden 10 Gründe, die für eine frühe Fehlbildungsdiagnostik mit 1114 SSW sprechen diskutiert. Diese Argumente unterstreichen den Nutzen einer detaillierten Ersttrimester-Sonografie als „Grundlage in der Planung und im Management“. Dieser Aspekt sollte nicht zugunsten einer Diagnostik aufgegeben werden, die lediglich bei einer Trisomie 21 besser abschneidet.

\section{Häufigkeit von fetalen Fehlbildungen und Chromosomenanomalien}

Die Schwangerenvorsorge sollte sich an der Inzidenz von Schwangerschaftskomplikationen orientieren und nicht allein an der Leistungsfähigkeit der verfügbaren Screeningtests im Einzelnen. Aufgrund der ausgezeichneten Detektions- und Falsch-Positiv-Rate des cfDNAScreeningstests für eine Trisomie 21 drängt sich die Versuchung auf, sich primär auf die Trisomie 21 zu konzentrieren, obwohl andere Komplikationen und Anomalien wesentlich häufiger auftreten [15]. Kurzum als Bespiel, das Risiko für eine Trisomie 21 steigt von etwa 1:1.250 bei einer 20-jährigen Frau auf etwa 1:90 bei einer 40-jährigen Frau. Im Gegensatz dazu liegt das Risiko für seltene Chromosomenstörungen bei 1:270 und für schwere Fehlbildungen bei etwa $2 \%$, für eine Präeklampsie bei $2 \%$, für eine intrauterine Wachstumsrestriktion bei $5 \%$ und für eine Frühgeburtlichkeit bei $10 \%$ [15-17]. Einige dieser Komplikationen können durch ein Ersttrimester-Ultraschall -Screening diagnostiziert oder vorbeugend behandelt werden. In Bezug auf Präeklampsie wurde gezeigt, dass durch ein kombiniertes Screening auf eine frühe Präeklampsie mit 11-14 SSW etwa 3/4 der betroffenen Schwangerschaften erkannt werden können, bei einer Falsch-Positiv-Rate von $10 \%$ [6]. Noch wichtiger ist, wie Rolnik et al. gezeigt haben, dass in der durch das Ersttrimester-Screening ermittelten Hochrisikopopulation das Risiko für eine frühe Präeklampsie durch die Gabe von Aspirin um bis zu 80 \% gesenkt wer- den konnte [7]. Die Tatsache, dass schwere Fehlbildungen und die Präeklampsie häufiger vorkommen als eine Trisomie 21 und dass es eine Präeklampsie-Prophylaxe für Hochrisikopatientinnen gibt, die mit 11-14 SSW identifiziert wurden, unterstreicht die Bedeutung einer detaillierten Risikobewertung im ersten Trimester.

\section{Entdeckungsraten von Fehlbildungen in der Schwangerschaft}

Die meisten Programme zur Schwangerschaftsvorsorge konzentrieren sich auf die Zweittrimester-Ultraschalluntersuchung als wichtigste Untersuchung zur Erkennung fetaler Fehlbildungen.

Dieser Ansatz impliziert, dass die Detektionsrate für Fehlbildungen in diesem Schwangerschaftsstadium höher ist. Im Eurocat-Register beträgt die Nachweisrate für Fehlbildungen im gesamten Schwangerschaftsverlauf jedoch nur etwa $40 \%$ [18]. Nach einer Metaanalyse des Deutschen Instituts für Qualität und Wirtschaftlichkeit im Gesundheitswesen betrug die Detektionsrate für Fehlbildungen ebenfalls nur 44,5\% bei einer Falsch-Positiv-Rate von 0,1\% [19]. Rydberg und Tunon stellten ähnliche Detektions- und Falsch-Positiv-Raten fest [20]. Ihre Studie basierte auf mehr als 10000 Schwangerschaften und 243 Feten mit schweren Fehlbildungen.

Diese Raten sind enttäuschend, insbesondere im direkten Vergleich mit dem Potenzial der verfügbaren Screeningtests für häufige Trisomien [21].

Es gibt im Wesentlichen 2 verschiedene Ansätze, um die Detektionsrate von schweren Fehlbildungen zu erhöhen: ein besseres Schulungsprogramm für das medizinische Fachpersonal und/oder eine Verlegung des Zeitpunkts, in dem der Fetus untersucht wird.

Der zweite Ansatz scheint vielversprechender zu sein. In einer Metaanalyse von Karim et al. lag die Detektionsrate für schwere Fehlbildungen mit 11-14 SSW bei $46 \%$ und in einer Hochrisikopopulation sogar bei 61 \% [5]. Liao's Studie mit mehr als 50000 Ersttrimester-Fehlbildungsuntersuchungen zeigte eine Detektionsrate von $43 \%$ [22].

Somit ist die Detektionsrate für Fehlbildungen bei der Ersttrimester-Untersuchung ähnlich hoch wie die Detektionsrate in der gesamten Schwangerschaft, und in einer Hochrisikopopulation ist sie sogar noch höher. Zu berücksichtigen ist aber, dass die Daten aus Ersttrimesterstudien mit den klinischen Daten aus dem zweiten Trimenon verglichen werden; es gibt jedoch keine neueren Studien, die die Detektionsrate fetaler Fehlbildungen im zweiten Trimester in einem Studienkollektiv untersuchen.

Eine Hochrisikopopulation könnte mithilfe von sonographischen Markern wie der Nackentransparenz, dem Ductus-venosus-Fluss oder Fossa-posterior-Parametern definiert werden [2329]. Diese Marker sind bekannte Ersttrimesterparameter, die in hohem Masse mit größeren strukturellen Fehlbildungen korrelieren. Im zweiten Trimester gibt es dagegen keine derartigen vergleichbar guten Marker.

Zusammenfassend lässt sich festhalten, dass auch die Zweittrimester-Untersuchung einen beträchtlichen Anteil von Fehlbildungen nicht erkennen kann. Das Ersttrimester-Screening zeigt zumindest ähnliche Detektionsraten. Selbst wenn die Zweittrimester-Fehlbildungsdiagnostik durch eine Untersuchung im ersten 
Trimester mit zusätzlichen Hinweiszeichen (aus dem ersten Trimester) ersetzt würde, ist zu vermuten, dass die Detektionsrate ähnlich hoch oder sogar noch höher wäre. Der leistungsstärkste Ansatz ist jedoch der kombinierte Einsatz von Erst- und Zweittrimester-Fehlbildungsdiagnostik mit Detektionsraten von mehr als $80 \%$ [30].

\section{Adipositas}

Adipositas ist eine der größten Gesundheitsbelastungen mit zunehmender Bedeutung in der Geburtshilfe und Pränatalmedizin [31, 32]. Estwood et al. zeigten, dass sich die Bildqualität mit steigendem BMI verschlechterte. In ihrer Studie war in der Gruppe von Frauen mit einem BMl ab 40 kg/m2 fast ein Viertel der Zweittrimester-Ultraschalluntersuchungen nicht vollständig [33]. Andere Studien kommen zu ähnlichen Ergebnissen und betonen die Notwendigkeit einer zusätzlichen Ultraschalluntersuchung zu einem späteren Zeitpunkt, um die anatomische Beurteilung zu vervollständigen [34].

Eine frühe anatomische Beurteilung mit 11-14 SSW könnte eine nützliche Alternative darstellen. Im Gegensatz zur Zweittrimesteruntersuchung kann im ersten Trimenon der Ultraschall mittels transvaginaler Sonographie ggf.mit sanften Drucks auf die mütterliche Bauchdecke durchgeführt werden. In den meisten Fällen kann die anatomische Beurteilung bei adipösen Frauen in diesem frühen Schwangerschaftsstadium erfolgreicher durchgeführt werden als nach 20 Schwangerschaftswochen. Dies wurde auch von Toscano at al. gezeigt, die den Erfolg der anatomischen Beurteilung im ersten und zweiten Trimester bei Frauen mit einem BMI $>35 \mathrm{~kg} / \mathrm{m} 2$ verglichen haben[35]. Die anatomische Untersuchung des Feten konnte bei $62 \%$ der Frauen im 2. Trimenon vollständig durchgeführt werden im Vergleich zu 78 \% mit zusätzlicher früher transvaginaler Untersuchung. Die Autoren schlussfolgerten, dass bei Adipositas die zusätzliche frühe transvaginale anatomische Beurteilung zu einer besseren abschliessenden Befundung führt, und das in einem früheren Gestationsalter.

\section{Darstellung fetaler Strukturen}

Zahlreiche Studien haben gezeigt, dass mit 11-14 SSW bestimmte Anomalien in fast allen Fällen diagnostiziert werden können. Dazu gehören die Anenzephalie, Holoprosenzephalie, Bauchwanddefekte, die Body stalk Anomalie und die Megazystis [11].

Einige Anomalien sind im ersten Trimester noch besser zu erkennen als im Zweiten. Dazu gehören die Gastroschisis und kleine Omphalozelen, die nur Darm enthalten, Retrognathien sowie Hand- und Fingerfehlbildungen. Bei Bauchwanddefekten und Handfehlbildungen z. B. kann die Diagnose in Schwangerschaften mit verminderter Fruchtwassermenge zu einem späteren Zeitpunkt schwierig sein. Zudem ist z. B. eine Retrognathie im ersten Trimester im Allgemeinen am stärksten ausgeprägt [36].

Einschränkend zu erwähnen ist aber, dass dies persönliche Erfahrung sind und es z. T. hierzu keine oder wenige Studien gibt, die einige dieser Beobachtung stützen.

\section{Unklare und unzureichende zellfreie DNA-Analysen}

Obwohl der NIPT auf häufige Trisomien eine hohe Sicherheit bietet, gibt es 2 Schwachstellen, die berücksichtigt werden müssen:
Erstens sind etwa 2-5\% der cfDNA-Analysen nicht erfolgreich, hauptsächlich aufgrund einer zu niedrigen fetalen Fraktion unter dem Schwellenwert von 4 \% [37-39]. Der NIPT kann einige Wochen später wiederholt werden, da die fetale Fraktion in der Schwangerschaft durchschnittlich um $0,1 \%$ pro Woche ansteigt. Etwa 2/3 dieser Zweitanalysen sind erfolgreich [38]. Bleibt die cfDNA-Analyse jedoch ergebnislos, so profitieren die Frauen nicht mehr von einer Risikobewertung für Trisomie 21.

Eine weitere Wiederholung der Analyse kann die Erfolgsquote nicht weiter erhöhen, und der kombinierte Ersttrimestertest wird aufgrund des erhöhten Gestationsalters nicht mehr möglich sein. Da die Zweittrimester-Fehlbildungsdiagnostik eine geringere Entdeckungsrate für eine Trisomie 21 hat, ist dann die diagnostische Punktion die einzige Alternative, um Aneuploidien zu erkennen [40]. Wenn sich alle Frauen mit einer unklaren cfDNA-Analyse für die invasive Pränataldiagnostik entscheiden, wird der wichtigste positive Effekt des cfDNA-Screenings - eine niedrige Rate an invasiver Diagnostik - verwässert [41].

Wenn die cfDNA-Analyse mit 11-14 SSW durchgeführt wird, dann kann die Nackentransparenz gleichzeitig mit der Blutentnahme für das cfDNA-Screening bestimmt werden, und eine weitere Blutprobe kann ggf parallel entnommen und aufbewahrt werden. Bei einer nicht aussagekräftigen cfDNA-Analyse können in der Rückstellprobe PAPP-A und freies beta-hCG nachgeholt werden, und das kombinierte Ersttrimesterrisiko kann für die Risikobewertung herangezogen werden [26].

Zweitens gibt es, wie bereits anesprochen, weitaus mehr Chromosomenanomalien als diejenigen, die mittels cfDNA-Analyse nachgewiesen werden können. Viele dieser Fälle zeigen eine erhöhte Nackentransparenz, stark abnorme Serummarker oder schwere fetale Fehlbildungen [26, 42-46]. Diese Befunde sind anstelle der cfDNA-Analyse eine Indikation für eine weitergehende diagnostische Abklärung. Natürlich können auch im zweiten Trimester größere Fehlbildungen festgestellt werden, aber die zusätzlichen Hinweise auf seltene Chromosomendefekte sind nach 20 SSW i. R. seltener von Nutzen.

\section{Zeitnahe Abklärung}

Aktuelle genetische Untersuchungen umfassen zytogenetische und Microarray-Analysenverfahren sowie Next-Generation-Sequencing Technologien (NGS) [47, 48]. Im Allgemeinen bestimmt die Indikation für den diagnostischen Test das Ausmass der genetischen Analyse. Bei Verdacht auf eine Trisomie ist die zytogenetische Analyse nach wie vor die Methode der Wahl, die bei Bedarf um einen Microarray erweitert wird. Bei multiplen Anomalien ohne pathologische zytogenetische oder Microarray-Ergebnis sind allerdings NGS-Methoden indiziert. Der größte Nachteil Letzterer ist, dass sie derzeit nicht als erste Wahl in der diagnostischen Abklärung stehen, sondern als Folgediagnostik durchgeführt werden und dass deren Dauer bis zur Befundstellung immer noch 24 Wochen betragen kann. Eine weiterführende Diskussion dieser Verfahrensweisen würde den Rahmen dieses Beitrags sprengen.

Wenn aber die Diagnostik fetaler Fehlbildungen bis 20 SSW aufgeschoben wird, kann der Zeitabstand zwischen der Beratung, der Entscheidungsfindung im Hinblick auf die Diagnostik und dem Endergebnis des genetischen Abklärung mehrere Wochen betra- 
gen. Entscheidet sich das Paar für einen Schwangerschaftsabbruch, müsste dieser im dritten Trimester erfolgen. In mehreren Ländern gibt es jedoch gesetzliche Beschränkungen, die einen so späten Abbruch nicht zulassen.

Wird eine Fehlbildung hingegen bereits zwischen 11-14 SSW festgestellt, bleibt ausreichend Zeit, um die gesamte Diagnostik vor 20 SSW abzuschließen.

\section{Entscheidungsfindung der Schwangeren}

Nach unserer Kenntnis gibt es keine Studien, die untersucht haben, ob Frauen eine Ultraschalluntersuchung im ersten oder im zweiten Trimester bevorzugen, um fetale Schäden diagnostizieren zu können. Es gibt jedoch ältere Studien, die zeigen, dass Schwangere, wenn sie die Wahl hätten, sich eher für ein Ersttrimester-Screening auf Trisomie 21 entscheiden würden als für ein Zweittrimester-Screening [49]. Ein Großteil der schwangeren Frauen hat nur begrenzte Kenntnisse über das Down-Syndrom. Für sie steht Trisomie 21 stellvertretend für eine Reihe von Behinderungen bei Feten und Neugeborenen. Folglich hat für sie das Trisomie-21-Screening eine viel größere Bedeutung, als die Trisomie 21 im eigentlichen Sinn.

Zu vermuten ist, dass der präferierte Zeitpunkt für die anatomische Beurteilung des Feten zwischen 11-14 SSW ist, und eine Trisomie 21 nur eine Umschreibung für ein Kind mit Behinderungen darstellt.

Die nächsten 3 Argumente beziehen sich auf den Schwangerschaftsabbruch und seine Komplikationen. Sie unterstreichen, dass ein Schwangerschaftsabbruch im ersten Trimester sicherer ist und weniger Langzeitkomplikationen mit sich bringt, als wenn er im zweiten Trimester vorgenommen wird. Daher sollte das Screening auf Aneuploidien und größere Fehlbildungen so früh wie möglich durchgeführt werden, um späte Abbrüche zu vermeiden.

\section{Risiken eines Schwangerschaftsabbruchs}

Mit zunehmendem Gestationsalter steigt das mütterliche Risiko bei einem Schwangerschaftsabbruch. Bartlett et al. untersuchten die mütterliche Mortalität nach einem Schwangerschaftsabbruch und stellten einen Anstieg von 38\% pro Woche fest [50]. Mark et al. konzentrierten sich auf die Morbidität in Fällen mit operativem Abbruch [51]. Die Gesamtkomplikationsrate betrug 2,2\%. Im zweiten Trimenon war die Komplikationsrate doppelt so hoch wie in der Ersttrimestergruppe. Dies galt insbesondere für übergewichtige Frauen. So lag die Komplikationsrate bei Frauen mit einem BMI von $40 \mathrm{~kg} / \mathrm{m} 2$ und mehr im ersten Trimenon bei 1,1\% und im zweiten Trimester bei 8,7\%.

\section{Psychische Folgen eines Schwangerschaftsabbruchs}

Ein Schwangerschaftsabbruch kann bei beiden Partnern zu lang anhaltenden psychischen Problemen führen. Korenromp et al. beobachteten bei $44 \%$ der Frauen posttraumatischen Stress und bei $28 \%$ Symptome einer Depression nach einem Schwangerschaftsabbruch. Die Partner waren in $22 \%$ (posttraumatischer Stress) bzw. 16\% (Depression) der Fälle betroffen [52]. Die Autoren suchten nach Prädiktoren für psychische Folgen und stellten fest, dass ein höheres Gestationsalter signifikant mit psychischen
Komplikationen assoziiert war. Vergleichbare Ergebnisse mit einer erhöhten posttraumatischen Belastung 6 Wochen nach Abbruch zeigte die Studie von Davies et al. im zweiten Trimenon verglichen mit einem Abbruch im ersten Trimenon [53].

\section{Dichoriale Zwillingsschwangerschaft mit schweren Fehlbildungen}

Die Entscheidungsfindung bei dichorialen Zwillingsschwangerschaften mit schwerer Fehlbildung eines Geminus ist besonders schwierig. Dem Wunsch, den gesunden Zwilling zu schützen, steht das potenzielle Bestreben gegenüber, die Schwangerschaft mit der fetalen Anomalie zu beenden. Die Methode der Wahl ist ein selektiver Schwangerschaftsabbruch, der aus dem Fetozid des betroffenen Zwillings und der Fortsetzung der Schwangerschaft besteht. Die Wahl des richtigen Zeitpunkts ist jedoch für diesen Ansatz von entscheidender Bedeutung.

Zemet al. untersuchten das Outcome selektiver Abbrüche bei dichorialen Zwillingsschwangerschaften zwischen der 15. und 23. SSW. Unter den verbliebenen Zwillingen waren $28 \%$ Frühgeburten, und 12,0\% wurden vor der 34. SSW geboren [54]. Bei selektiven Abbrüchen zwischen der 11 und 14Schwangerschaftswochen betrug dagegen die Frühgeburtenrate 14\% und nur 1,8\% der Schwangerschaften kamen vor der 34. SSW zur Welt.

Abschließend lässt sich sagen, dass mit den oben aufgeführten Argumenten die zunehmende Zahl und Vielfalt der pränataldiagnostischen Methoden nicht dazu führen muss, dass die detaillierte Ersttrimester-Fehlbildungsdiagnostik mit ihrem erwiesenen Nutzen aufgegeben wird, sondern dass vielmehr erhöhte und komplexere Anforderungen an diese gestellt werden. Der qualifizierte Ersttrimester-Ultraschall muss seine entscheidende Planungsund Triagefunktion beibehalten, um eine optimale Schwangerenvorsorge zu gewährleisten.

\section{Conflict of Interest}

The authors declare that they have no conflict of interest.

\section{References}

[1] Sonek JD, Kagan KO, Nicolaides KH. Inverted Pyramid of Care. Clinics in laboratory medicine 2016; 36: 305-317

[2] Nicolaides KH. A model for a new pyramid of prenatal care based on the 11 to 13 weeks' assessment. Prenatal diagnosis 2011; 31: 3-6

[3] Kagan KO, Wright D, Valencia C et al. Screening for trisomies 21, 18 and 13 by maternal age, fetal nuchal translucency, fetal heart rate, free-hCG and pregnancy-associated plasma protein-A. Human Reproduction 2008; 23: 1968-1975

[4] Santorum M, Wright D, Syngelaki A et al. Accuracy of first-trimester combined test in screening for trisomies 21, 18 and 13. Ultrasound Obstetrics Amp Gynecol 2017; 49: 714-720

[5] Karim JN, Roberts NW, Salomon L] et al. Systematic review of first-trimester ultrasound screening for detection of fetal structural anomalies and factors that affect screening performance. Ultrasound Obst Gyn 2017; 50: 429-441

[6] O'Gorman N, Wright D, Poon LC et al. Accuracy of competing-risks model in screening for pre-eclampsia by maternal factors and biomarkers at 1113 weeks' gestation. Ultrasound in Obstetrics \& Gynecology 2017; 49: 751-755 
[7] Rolnik DL, Wright D, Poon LC et al. Aspirin versus Placebo in Pregnancies at High Risk for Preterm Preeclampsia. New England Journal of Medicine 2017; 377: 613-622

[8] Rolnik DL, Wright D, Poon LCY et al. ASPRE trial: performance of screening for preterm pre-eclampsia. Ultrasound in Obstetrics \& Gynecology 2017; 50: 492-495

[9] von Kaisenberg C, Chaoui R, Häusler M et al. Quality Requirements for the early Fetal Ultrasound Assessment at 11-13+6 Weeks of Gestation (DEGUM Levels II and III). Ultraschall in der Medizin - European Journal of Ultrasound 2016; 37: 297-302

[10] Nicolaides KH. Turning the Pyramid of Prenatal Care. Fetal diagnosis and therapy $2011 ; 29: 183-196$

[11] Kozlowski P, Burkhardt T, Gembruch U et al. DEGUM, ÖGUM, SGUM and FMF Germany Recommendations for the Implementation of FirstTrimester Screening, Detailed Ultrasound, Cell-Free DNA Screening and Diagnostic Procedures. Ultraschall in der Medizin (Stuttgart, Germany: 1980) 2019; 40: 176-193

[12] Kagan KO, Eiben B, Kozlowski P. Kombiniertes Ersttrimesterscreening und zellfreie fetale DNA - „Next Generation Screening“. Ultraschall in der Medizin (Stuttgart, Germany : 1980) 2014; 35: 229-236

[13] Quezada MS, Gil MM, Francisco C et al. Screening for trisomies 21, 18 and 13 by cell-free DNA analysis of maternal blood at 10-11 weeks' gestation and the combined test at 11-13 weeks. Ultrasound Obst Gyn 2015; 45: 36-41

[14] Gil MM, Accurti V, Santacruz B et al. Analysis of cell-free DNA in maternal blood in screening for aneuploidies: updated meta-analysis. Ultrasound in Obstetrics \& Gynecology 2017; 50: 302-314

[15] Screening for Fetal Chromosomal Abnormalities: ACOG Practice Bulletin Summary, Number 226. Obstetrics Gynecol 2020; 136: 859-867

[16] Mol BW], Roberts CT, Thangaratinam S et al. Pre-eclampsia. Lancet 2016; 387: 999-1011

[17] Schleußner E. The prevention, diagnosis and treatment of premature labor. Deutsches Ärzteblatt international 2013; 110: 227-235 -quiz 236

[18] registry E. Prenatal detection rates charts and tables [Internet]. n. d. Available from: https://eu-rd-platform.jrc.ec.europa.eu/eurocat/ eurocat-data/prenatal-screening-and-diagnosis_en

[19] (IQWiG) I für Q und W im G. Dokumentation und Wuerdigung der Stellungnahmen zum Vorbericht Ultraschallscreening in der Schwangerschaft. 2005

[20] Rydberg C, Tunón K. Detection of fetal abnormalities by second-trimester ultrasound screening in a non-selected population. Acta Obstetricia et Gynecologica Scandinavica 2017; 96: 176-182

[21] IQWiG I für Q und W im G. Nichtinvasive Pränataldiagnostik (NIPD) zur Bestimmung des Risikos autosomaler Trisomien 13, 18 und 21 bei Risikoschwangerschaften. 2017 Dec;1-118.

[22] Liao Y, Wen H, Ouyang S et al. Routine first-trimester ultrasound screening using a standardized anatomical protocol. Am J Obstet Gynecol 2020. doi:10.1016/j.ajog.2020.10.037

[23] Kenkhuis MJA, Bakker M, Bardi F et al. Yield of a 12-13 week scan for the early diagnosis of fetal congenital anomalies in the cell-free DNA era. Ultrasound in Obstetrics \& Gynecology 2017. doi:10.1002/uog.17487

[24] Bardi F, Smith E, Kuilman M et al. Early Detection of Structural Anomalies in a Primary Care Setting in the Netherlands. Fetal Diagn Ther 2019; 46: 12-19

[25] Wagner P, Sonek J, Eberle $\mathrm{K}$ et al. First trimester screening for major cardiac defects based on the ductus venosus flow in fetuses with trisomy 21. Prenatal diagnosis. 2018; 38: 561-566

[26] Kagan KO, Sroka F, Sonek J et al. First-trimester risk assessment based on ultrasound and cell-free DNA vs combined screening: a randomized controlled trial. Ultrasound in Obstetrics \& Gynecology 2018; 51: 437-444

[27] Minnella GP, Crupano FM, Syngelaki A et al. Diagnosis of major heart defects by routine first-trimester ultrasound examination: association with increased nuchal translucency, tricuspid regurgitation and abnormal flow in ductus venosus. Ultrasound Obst Gyn 2020; 55: 637-644

[28] Souka AP, Kaisenberg CSV, Hyett JA et al. Increased nuchal translucency with normal karyotype. American Journal of Obstetrics and Gynecology 2005; 192: 1005-1021

[29] Volpe N, Dall'Asta A, Pasquo ED et al. First-trimester fetal neurosonography: technique and diagnostic potential. Ultrasound Obst Gyn 2021; 57: $204-214$

[30] Syngelaki A, Hammami A, Bower S et al. Diagnosis of fetal non-chromosomal abnormalities on routine ultrasound examination at 11-13 weeks' gestation. Ultrasound in Obstetrics \& Gynecology 2019; 54: 468-476

[31] TG 2015 O.. Health Effects of Overweight and Obesity in 195 Countries over 25 Years. New England Journal of Medicine 2017; 377: 13-27

[32] Poston L, Caleyachetty R, Cnattingius S et al. Preconceptional and maternal obesity: epidemiology and health consequences. The lancet Diabetes \& endocrinology 2016; 4: 1025-1036

[33] Eastwood K-A, Daly C, Hunter A et al. The impact of maternal obesity on completion of fetal anomaly screening. J Perinat Med 2017; 45: 1061-1067

[34] Thornburg LL, Miles K, Ho M et al. Fetal anatomic evaluation in the overweight and obese gravida. Ultrasound Obst Gyn 2009; 33: 670-675

[35] Toscano M, Grace D, Pressman EK et al. Does transvaginal ultrasound at 13-15 weeks improve anatomic survey completion rates in obese gravidas? J Maternal-fetal Neonatal Medicine 2019; 34: 1-251

[36] Pasquo ED, Amiel J, Roth P et al. Efficiency of prenatal diagnosis in Pierre Robin sequence. Prenatal Diag 2017; 37: 1169-1175

[37] Yaron Y. The implications of non-invasive prenatal testing failures: a review of an under-discussed phenomenon. Prenatal diagnosis 2016; 36: 391-396

[38] Revello R, Sarno L, Ispas A et al. Screening for trisomies by cell-free DNA testing of maternal blood: consequences of a failed result. Ultrasound in Obstetrics \& Gynecology 2016; 47: 698-704

[39] Palomaki GE, Kloza EM, Lambert-Messerlian GM et al. DNA sequencing of maternal plasma to detect Down syndrome: an international clinical validation study. Genetics in medicine : official journal of the American College of Medical Genetics 2011; 13: 913-920

[40] Agathokleous M, Chaveeva P, Poon LCY et al. Meta-analysis of secondtrimester markers for trisomy 21 . Ultrasound in obstetrics \& gynecology : the official journal of the International Society of Ultrasound in Obstetrics and Gynecology 2013; 41: 247-261

[41] Grati FR, Kagan KO. Rate of no result in cell-free DNA testing and its influence on test performance metrics. Ultrasound in Obstetrics \& Gynecology 2017; 50: 134-137

[42] Tørring $\mathrm{N}$, Petersen OB, Becher $\mathrm{N}$ et al. First trimester screening for other trisomies than trisomy 21,18 , and 13 . Prenatal diagnosis 2015; 35: 612619

[43] Petersen OB, Vogel I, Ekelund C et al. Potenzial diagnostic consequences of applying non-invasive prenatal testing: population-based study from a country with existing first-trimester screening. Ultrasound in obstetrics \& gynecology : the official journal of the International Society of Ultrasound in Obstetrics and Gynecology 2014; 43: 265-271

[44] Syngelaki A, Guerra L, Ceccacci I et al. Impact of holoprosencephaly, exomphalos, megacystis and increased nuchal translucency on firsttrimester screening for chromosomal abnormalities. Ultrasound in Obstetrics \& Gynecology 2017; 50: 45-48

[45] Syngelaki A, Pergament E, Homfray T et al. Replacing the combined test by cell-free DNA testing in screening for trisomies 21, 18 and 13: impact on the diagnosis of other chromosomal abnormalities. Fetal diagnosis and therapy 2014; 35: 174-184

[46] Kagan KO, Hoopmann M, Hammer R et al. Screening for chromosomal abnormalities by first trimester combined screening and noninvasive prenatal testing. Ultraschall in der Medizin (Stuttgart, Germany : 1980) 2015; 36: 40-46 
[47] Sabbagh R, den Veyver IBV. The current and future impact of genomewide sequencing on fetal precision medicine. Hum Genet 2020; 139: $1121-1130$

[48] Chong HP, Hamilton S, Mone F et al. Prenatal chromosomal microarray testing of fetuses with ultrasound structural anomalies: A prospective cohort study of over 1000 consecutive cases. Prenatal diagnosis 2019; 39: 1064-1069

[49] Mulvey S, Wallace EM. Women's knowledge of and attitudes to first and second trimester screening for Down's syndrome. Bjog Int J Obstetrics Gynaecol 2000; 107: 1302-1305

[50] Bartlett LA, Berg C], Shulman HB et al. Risk factors for legal induced abortion-related mortality in the United States. Obstetrics and gynecology 2004; 103: 729-737
[51] Mark KS, Bragg B, Talaie T et al. Risk of complication during surgical abortion in obese women. American journal of obstetrics and gynecology 2017. doi:10.1016/j.ajog.2017.10.018

[52] Korenromp M], Page-Christiaens GCML, van den Bout J et al. A prospective study on parental coping 4 months after termination of pregnancy for fetal anomalies. Prenatal Diag 2007; 27: 709-716

[53] Davies V, Gledhill J, McFadyen A et al. Psychological outcome in women undergoing termination of pregnancy for ultrasound-detected fetal anomaly in the first and second trimesters: a pilot study. Ultrasound in obstetrics \& gynecology : the official journal of the International Society of Ultrasound in Obstetrics and Gynecology 2005; 25: 389-392

[54] Zemet R, Haas ], Bart Y et al. Optimal timing of fetal reduction from twins to singleton: earlier the better or later the better? Ultrasound Obst Gyn 2021; 57: 134-140 